\title{
Influence Of Budget Deficit On Economic Growth: The Case Of The Republic Of Macedonia*
}

Aleksandar NIKOLOSKI** Pece NEDANOVSKI ${ }^{* * *}$

\begin{abstract}
Having a balanced budget is very important for achieving long-term and stable economic growth in everyone country. Namely, the budget itself is a very powerful and useful tool and instrument for defining and realizing development policies in a country. The usefulness and the efficiency of this instrument largely depend on whether it is balanced or in deficit. Structural budget deficit cannot be analyzed if abstracted and separated because it influences large number of macroeconomic trends, but it is also under influence of numerous macroeconomic factors. And fiscal factors, as structure of public expenditure, structure of public revenue, government efficiency, level of tax avoidance and tax evasion, level of income and wealth inequality etc.
\end{abstract}

The stands of economic theory differ when it comes to the influence the budget deficit has on the economic growth of a country. According to some theoreticians this link is positive; according to others it is inverse one whereas according to third party of them there is a neutral connection between the budget deficit and the economic growth. The classic macroeconomic paradigm perceived budget deficit as an enemy of the economy due to the line of negative effects it causes. However, in the course of time governments accepted budget deficit as an instrument that can boost public investments which further lead to stimulating long-term economic growth. Namely, when it comes to the stabilization policies of a country, the idea about budget deficit can be stressed out, and the budget deficit representing a reflection of either the increase in public expenditure or the decrease of the distortive taxes, all for the purpose of having the economy maintain its trend of a stable and long-term growth.

The causal connection between the deficit and the economic growth can be perceived through the fact that positive economic growth generates additional public revenues. Therefore, the government is the one that should choose between cycle or counter-cycle fiscal policy. Negative economic growth causes contraction in the economy, and as a result of this it is certain that the expansive fiscal policy accompanied by large budget deficit is not appropriate in periods of economic growth.

Countries should make a rational use of their unused resources if they want to overcome the issues related to budget deficit. Most often providing funds through indebting is not a good solution because it leads to increase in the public debt. Consequently, governments often decide to increase the rates of direct and indirect taxes or to introduce a new form of tax that is expected to increase the rates of public revenues and to reduce the budget deficit. The structure of fiscal policy should be appropriately formulated so as to enable the taxpayers to bear certain tax burden, and the tax incentives to alleviate the is sue of tax evasion. The outcome of this all would be having higher tax income and lower budget deficit.

Economic growth has reversible influence on budget deficit. In fact, the best way to decrease budget deficit is to promote economic growth. If economy is in progress, then it is real to expect increased tax revenues, without having the necessity to increase tax rates. Therefore, boosting economic growth is the least painful way to decrease budget deficit. Having all that in mind, governments should be careful when planning public revenues and expenditures i.e. when planning the budget deficit level, all for the purpose of creating preconditions for reaching the aimed level of economic growth.

It is this paper's aim to analyze the influence of budget deficit on the economic growth in the case of the Republic of Macedonia. In the context of the appropriate econometric model, budget deficit is represented as a main independent variable, and the gross domestic product as a dependent variable. Meanwhile, there shall be inspected what is the possible influence and how significant it is and whether it is possible to be delivered in short or long term perspective. While testing the model, two basic tests are used i.e. Breusch-Godfrey test for serial correlation and Breusch-Pagan-Godfrey test for heteroskedasticity. By making use of the presented model there should be clarified what is the connection between public finance and economic growth in the Republic of Macedonia as a potential EU member country. A significant prerequisite for doing so is having a detailed examination of whether public finance provide basis that further contributes for short-term influence on economic performances thus boosting economic growth.

Larger number of empirical research point out that the level of budget deficit of over $3 \%$ of the gross domestic product leads to deceleration of economic growth. In cases when deficit is less than $1.5 \%$ of the GDP, it is neutral in respect to economic growth. This statement is not valid for the case of the Republic of Macedonia, because in 2003 budget deficit totaled $4.1 \%$ of the GDP and at the same time the growth rate was $2.9 \%$ of the GDP. According to our findings, budget deficit should not be bigger than $6 \%$ of GDP in order not to have negative effect on the economic growth. This is also supported with the constructed econometric model, which simultaneously shows that much greater is the influence of other factors on the economic growth compared to the budget deficit. The results of the model show that on a level of importance of 5\%, the budget is positively correlated with the GDP growth rate on a long-run. Decrease in budget deficit for $1 \%$ shall lead to increase in GDP growth rate for $0.35 \%$. The value of the determinant coefficient is relatively low $(17.44 \%)$, which shows us the low influence budget deficit has on the economy growth rate. Therefore, a conclusion can be drawn that by making use of fiscal policy a relevant influence can be made on the economic growth in the long run.

Keywords: Economic growth, budget deficit, cause relation, Republic of Macedonia

* This article was presented as a paper at the IV. International Symposium on Accounting and Finance in Ohrid, Macedonia, July 3-5, 2017.

** Aleksandar Nikoloski, Ss. Cyril and Methodius University in Skopje, Faculty of Economics, n.aleksandar1@hotmail.com.

*** Prof. Pece Nedanovski, Ss. Cyril and Methodius University in Skopje, pecen@eccf.ukim.edu.mk. 


\section{INTRODUCTION}

The budget as a plan of revenues and expenditures of the government is an important instrument of economic policy. When actual costs are in line with the plan, it seems to have an adequate budgetary planning. Of course, the budget could be in deficit or in surplus, but in modern circumstances budgets of individual governments are often in a situation of deficit since public expenditures exceed revenues collected through tax and non-tax sources. But the deficit could also be a result of delays in the collection of revenues, i.e. taxes or other revenue sources.

There are three different views about the impact of budget deficits on economic growth. Namely, according to supporters of the Keynesian school, there is a positive relationship between these two variables. Neo-classicists believe that this relationship is inverse, while representatives of Ricardo's school defend the view that there is neutral connection between the budget deficit and economic growth.

Most analysis and research in the area of public finance measure the cumulative impact that the budget deficit has on the economy. Back in the time when the throne was on classical macroeconomic school, the budget deficit was seen as the great enemy of the economy due to a number of distortionary effects it causes.

Having in mind all the previous, basic macroeconomic implications of the budget deficit are as following:

- An increase in the borrowing of the country. The government will have to borrow from the private sector through the sale of bonds to cover the lack of funds in the budget.

- Increasing the interest of the debt. The sale of bonds will increase the national debt further by the amount of the interest. It creates additional intergenerational problem because in the future there was a need for future generations to pay higher taxes.

- An increase in aggregate demand. The budget deficit may occur as a result of lower tax revenues or increased government spending. The second option causes the growth of aggregate demand, and on the other hand it can initiate raise of inflation rate.

- In the future the Government can raise taxes and/or cut spending in order to reduce the deficit. It can discourage private initiative and business activities.

- An increase in interest rates. If the Government sells higher amount of bonds, it would cause a rise in interest rates. Namely, in order to make the bonds more attractive for investors, interest rates should be higher, i.e. to carry a higher yield.

- The effect of "crowding out" is also a possible consequence of the budget deficit. The rise in interest rates could have the effect of crowding out the private sector in the field of investment.

- Increasing the rate of inflation. In extreme cases, the government can initiate 
an increase in the money supply in order to pay the debt (monetized the public debt). If in this case the government has offered the banking sector short-term securities, it can cause a rise in the money supply because banks consider bonds more attractive for investing.

Taking this into consideration, our objective in this segment is to examine what is the impact of the budget deficit on economic growth in the Republic of Macedonia for the period from 2000 to 2015 . The analysis starts from the view that economic theory primarily deals regulatory aspects of fiscal policy. However, the implementation of fiscal policy in modern economies often deviate from the basic principles promoted by contemporary macroeconomic theory.

\section{LITERATURE REVIEW}

This issue was explored by many theoreticians so far. Kneller, Gemmell, and Bleaney (1999), in their analysis indicated that budget deficits may have different effects on economic growth, depending on how they were created. Consequently, while respecting budgetary constraints laid down by the Government, they brought the following conclusions:

- If the budget deficit is a result of reducing the distorting taxes, the effect on economic growth would be positive one.

- If the budget deficit is a result of reduced not distortionary taxes, economic growth would not be achieved.

- If the budget deficit is a result of increasing the productive government expenditures, the effect on economic growth would be positive.

- If the budget deficit is a result of increasing the unproductive government expenditures, the economic growth will not be achieved, and the growth rate can be reduced if the amplitude of the deficit is a significant one.

Adama and Bevan (2005), analyzing the budget deficit of 45 developed countries found a close link between deficit and economic growth. They conclude that from one side, reducing the budget deficit to $1.5 \%$ of gross domestic product (GDP) causes a positive impact on the growth rate of GDP. But, from the other side, reducing the budget deficit below this limit, did not initiate positive effects on economic growth, and it can be harmful due to significant fiscal contractions.

Fisher (1993) proved the opposite of what had hitherto brought forward a series of previous economists in their forecasts. He analyzed a consistent sample of countries, and the results showed a reverse causal relationship between the budget deficit and economic growth. Namely, according to Fisher, the budget deficit leads to a reduction of capital accumulation and productivity growth, with obvious negative impact on the growth rate of GDP.

Gupta and Baldacci (2005) have shown that keeping the budget deficit at a reasonable level is linked with economic growth, in the short and the long term. The 
composition of public expenditures and revenues is important to the overall impact of the budget deficit on economic growth. In countries where public expenditures are directed primarily to pay for public administration, it was observed a lower rate of growth of GDP, while in countries where public expenditures are mainly directed towards investments and purchases of goods and services, the situation is reversed.

\section{METHODOLOGY}

The research used secondary data sources for the budget balance and the rate of growth of GDP of the Republic of Macedonia for the period from 2000 to 2015. In order to determine the relationship between the budget deficit and economic growth, a regression analysis was conducted. With the help of the analysis, it should be determined whether there is influence of the budget balance on the real growth rate of GDP, as an indicator of economic growth.

The economic implications of the budget deficit can be identified by running simple econometric tests of linear regression. With these tests, from one hand it should be confirmed or denied the existence of a correlation between the dependent variable and one or more independent variables. On the other hand, if their connection is tested, it can be made estimation of the intensity of the connection.

In our case, as a dependent variable was highlighted the macroeconomic growth expressed by the rate of growth of real GDP. As an independent variable was taken the Government budget balance. Thus, the econometric model will get the following form:

$$
\begin{aligned}
& \mathrm{RGG}=\mathrm{C}+\beta \mathrm{BS}+\varepsilon \quad \text { where: } \\
& \mathrm{RGG}=\text { real rate of growth of GDP } \\
& \mathrm{BS}=\text { budget balance } \\
& \mathrm{C}=\text { constant } \\
& \varepsilon=\text { stochastic member (random error) } \\
& \beta=\text { coefficient } \\
& \mathrm{t}=\text { time period. }
\end{aligned}
$$

To test the strength of the model and the relationship between economic growth and the categories of public revenues, an analysis of variance (ANOVA) was realized. In determining the ANOVA analysis, the appropriate statistical value was received. Our test was implemented in the confidence interval of $95 \%$ (i.e. an accuracy of 95\%), and the significance level of 5\%. If the results are lower than the p-value $=5 \%$, then you a conclusion can be derived that the model is statistically significant for explaining the relationship; otherwise the model is not significant. 


\section{FINDINGS}

The main idea under which governments would accept the budget deficit in order to boost public investments that will have a positive impact on growth in the long term, was first introduced by John Maynard Keynes. His thesis actually constituted a recommendation to governments of developed countries at the time to overcome the global economic crisis and for economic recovery.

The modern theory of public finance synthesizes three roles that each government should achieve in the economy: allocative, distributive and stabilization role (Musgrave, 1989). From the position of the stabilization role of government in the economy, it can be extracted the idea of the budget deficit (as a result of increased public revenues or reduced distorting taxes). This idea was accepted in order to maintain the stable growth of the economy on long term. Having in mind the previous, the evolution of the budget balance and the rate of growth of GDP of the R. of Macedonia can be seen from the following Figure.

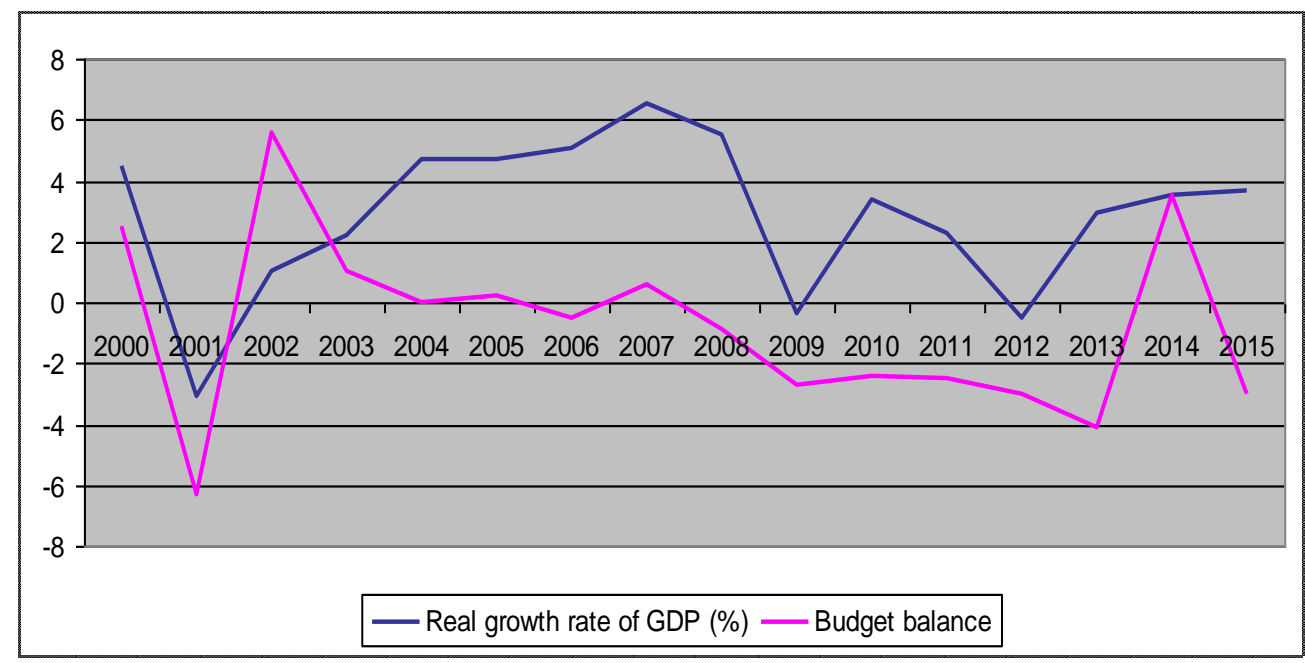

Figure 1. Evolution of the budget balance and the rate of growth of GDP in the R. of Macedonia for the period 2000-2015

Source: Ministry of Finance, Republic of Macedonia, Skopje.

Shown evolution of both macroeconomic indicators in the country as of 2000 failed to emphasize the interdependence between them, which means that there are other factors having significant impact on economic growth. But from Figure 1, it can be separated the manifestation of excessive budget deficits which was accompanied by a significant drop in GDP. Namely in 2001 when the budget deficit was $6.3 \%$, the real rate of GDP growth dropped to $3.1 \%$.

Most of empirical studies reveal that the budget deficit above 3\% of GDP hindering and slowing down economic growth, while the deficit of less than $1.5 \%$ of GDP is neutral or has no effects on growth. But this argument does not apply in the case of Macedonia, because in 2003 the budget deficit was 4.1\% of GDP, while the growth rate was $2.9 \%$.

From the analysis above arises the conclusion that the budget deficit should not 
exceed 6\% of GDP in order to have negative implications for the economic growth rate. Here again it should be noted that in our case, other and different factors have much greater impact on the rate of economic growth. Such conclusions will be backed up using the econometric estimates derived through software package EViews.

Table 1. Results of the assessment of the relationship between the budget balance and the real growth rate of GDP

\begin{tabular}{|c|c|c|c|c|}
\hline \multicolumn{5}{|c|}{$\begin{array}{l}\text { Dependent Variable: GDP_GROWTH } \\
\text { Method: Least Squares } \\
\text { Date: 03/22/17 Time: 00:11 } \\
\text { Sample: } 20002015 \\
\text { Included observations: } 16\end{array}$} \\
\hline Variable & Coefficient & Std. Error & t-Statistic & Prob. \\
\hline $\mathrm{C}$ & 3.139458 & 0.619613 & 5.066804 & 0.0002 \\
\hline BUDGET_BALANCE & 0.352611 & 0.205034 & 1.719768 & 0.1075 \\
\hline R-squared & 0.174412 & \multicolumn{2}{|c|}{ Mean dependent var } & 2.875000 \\
\hline Adjusted R-squared & 0.115441 & \multicolumn{2}{|c|}{ S.D. dependent var } & 2.552776 \\
\hline S.E. of regression & 2.400912 & \multicolumn{2}{|c|}{ Akaike info criterion } & 4.706043 \\
\hline Sum squared resid & 80.70127 & \multicolumn{2}{|c|}{ Schwarz criterion } & 4.802616 \\
\hline Log likelihood & -35.64834 & \multirow{2}{*}{\multicolumn{2}{|c|}{$\begin{array}{l}\text { Hannan-Quinn criter. } \\
\text { Durbin-Watson stat }\end{array}$}} & 4.710988 \\
\hline F-statistic & 2.957603 & & & 1.391242 \\
\hline Prob(F-statistic) & 0.107493 & \multicolumn{2}{|c|}{ Durbin-Watson stat } & \\
\hline
\end{tabular}

Source: Authors' calculations.

The results of the econometric model show that at the level of statistical significance of $5 \%$, the budget balance is positively correlated with the rate of GDP growth in the long term. The standard error is less than the estimated coefficient of the independent variable and the corresponding value of t-statistics. Also, the probability that the value of the coefficient is wrongly estimated is low (10.75\%). All this tells us that the coefficient is properly assessed.

Table 2. Examination of the autocorrelation in the model

\begin{tabular}{|lrlr|}
\hline \multicolumn{4}{|l|}{ Breusch-Godfrey Serial Correlation LM Test: } \\
\hline \hline F-statistic & 0.583939 & Prob. F(2,12) & 0.5728 \\
Obs*R-squared & 1.419062 & Prob. Chi-Square(2) & 0.4919 \\
\hline \hline
\end{tabular}

Source: Authors' calculations.

Autocorrelation problem faced by econometric models, occurs if there is a correlation between stochastic members. The autocorrelation is not present in our model. The value of Breusch-Godfrey Serial Correlation LM Test statistics (0.58), at a level of significance of $5 \%$ is less than the critical value of 5.991 . 
Table 3. Examination of Heteroskedasticity

\begin{tabular}{|llll|}
\hline \multicolumn{4}{ll|}{ Heteroskedasticity Test: Breusch-Pagan-Godfrey } \\
\hline \hline F-statistic & 0.000427 & Prob. F(1,14) & 0.9838 \\
Obs*R-squared & 0.000488 & Prob. Chi-Square(1) & 0.9824 \\
Scaled explained SS & 0.000195 & Prob. Chi-Square(1) & 0.9889 \\
\hline \hline
\end{tabular}

Source: Authors' calculations.

The problem of heteroskedasticity (i.e. the random errors in the regression equation should have different variances), is absent from our model, too. This is confirmed by the fact that f-statistics of the test is less than the critical value, i.e. $0.00042<5.991$.

Looking at the coefficient of budget balance may bring the basic conclusion that reducing the budget deficit by $1 \%$ would cause an increase in the rate of GDP growth by $0.35 \%$.

The coefficient of determination is relatively low (0.17), which tells us that the budget deficit has little impact on economic growth in the R. of Macedonia, i.e, other important determinants have impact on the rate of growth of GDP. In other words, the equation describes the time evolution of the growth rate of GDP in the amount of $17.44 \%$.

Table 4. Analysis of the variance (ANOVA)

\begin{tabular}{|ll|r|r|r|r|r|}
\hline \multicolumn{1}{c|}{ ANOVA $^{\text {a }}$} \\
\hline Model & Sum of Squares & \multicolumn{1}{c|}{ df } & Mean Square & \multicolumn{1}{c|}{ F } & \multicolumn{1}{c|}{ Sig. } \\
\hline 1 & Regression & 17,049 & 1 & 17,049 & 2,958 &, $107^{\mathbf{b}}$ \\
& Residual & 80,701 & 14 & 5,764 & & \\
& Total & 97,750 & 15 & & & \\
\hline
\end{tabular}

a. Dependent Variable: economic growth

b. Predictors: (Constant), budget balance

Source: Authors' calculations.

Analyzing the results of ANOVA test, it can be concluded that the significance of the model is 0.107 which is far greater than the value $\alpha=0.05$. It tells us that the regression model is not significant in predicting the relationship between the budget deficit and the growth rate of GDP, which is logical finding from the low coefficient of determination.

At the significance level of 5\%, calculated F-value model is 2.958. This value is lower than the critical F-value of 5.4095, which once again confirms that the model is not significant.

\section{CONCLUSIONS}

In the context of the research the relationship between the budget deficit and the economic growth of the Republic of Macedonia was analyzed. A prerequisite for this is to determine whether public finances provide instruments that contribute to fostering 
economic growth and determining whether there is a short-term impact on economic performances.

However when one looks at the stochastic trends in the model, it seems that both variables, i.e. public finances and the rate of economic growth are stable. This model does not exclude mutual long-term impacts between fiscal variables.

From the tested model the conclusion arises that budget deficit is inversely proportional to the rate of economic growth. In other words, reducing the budget deficit by 1 percentage point would cause an increase in the growth rate of GDP by 0.35 percentage points. The impact of the budget deficit on the rate of economic growth is relatively low, suggesting that the economic growth of $\mathrm{R}$. of Macedonia is affected by other important determinants. However, the conclusion is that fiscal policy can have an impact on economic growth in the long term.

The main findings indicate that on long term, the expenditure side of the budget has primary impact on the growth of the economy Namely, the size of the government spending has a negative effect on economic growth as opposed to public investments that have a positive impact.

There are evidences that direct taxes on the revenue side of the budget have negative effects on economic growth. The strong negative impact resulting from direct taxation of capital is evidenced by a series of empirical research and studies. This effect arises from the taxation of labour, which could lead to pressure on wages. This causality between economic growth and budget deficit arises from the fact that the positive economic growth generates additional public resources. Furthermore, the Government will choose between adopting cyclical or counter-cyclical fiscal policy. Because the negative economic growth causes a decrease in economic activity, it can be concluded that expansionary fiscal policy accompanied by a large budget deficit, is not appropriate in periods of expansion in the economy.

The negative impact of the budget deficit on economic growth comes from the fact that governments are faced with a lack of resources to cover all public expenditures in the long run. Their savings and incomes are not sufficient to meet their expenditures. Faced limited resources, the various development projects of the governments, on the one hand generate growth potential, but on the other hand they could initiate danger of meeting the expenditures (wages) of public administration (including some incidental expenses).

Governments in contemporary circumstances must use their unemployed resources in the most productive way, in order to overcome the problems with budget deficits. Taking loans to cover current public expenditures in short-run, is not a good solution. On the other hand printing more money for internal use, would increase the circulation of money which stimulates the purchasing power of the population, and it encourages inflation in the country. This solution is not the appropriate way to cover state expenditures, too. Consequently, the best option for the Government would be to raise the rates of direct and indirect taxes or to implement a kind of new tax as a solution for increasing the public revenues. In that case, the both previous negative effects shall be missed. 
Fiscal policy makers should create effective and efficient policy for improved tax collection. However it is recommended that the entire process of taxation should be under control in order to ensure fair and equitable taxation, i.e. to reduce the fiscal burden for tax payers. In this regard fiscal policy should be so framed as to encourage the wealthier tax payers to pay higher taxes or through certain incentives to solve the problem of tax evasion.

It is well known that the economic growth is influenced not only by the budget deficit itself. It requires further in-depth research to identify other factors that influence growth and to analyze their interrelation. It is also needed to make further research to study the relationship between public revenues and public expenditures from one hand, and the growth rate of GDP from the other hand. Hence, one can determine which items of revenues or expenditures side of the budget, the Government will have to emphasize to generate positive incentives in the economy.

It would be a good idea to test our model at different times in order to verify the results of the research. This type of research will be useful for economic policy makers in the country, to formulate specific policies that will be useful for achieving the desired level of economic growth.

\section{CONTRIBUTIONS}

Table 5. Budget balance and the real growth rate of GDP in the Republic of Macedonia (2000-2015 year)

\begin{tabular}{|c|c|c|}
\hline \multirow{2}{*}{ Year } & Real growth rate of GDP $(\%)$ & Budget balance \\
\hline 2000 & 4.5 & 2.5 \\
\hline 2001 & -3.1 & -6.3 \\
\hline 2002 & 1 & 5.6 \\
\hline 2003 & 2.2 & 1 \\
\hline 2004 & 4.7 & 0 \\
\hline 2005 & 4.7 & 0.2 \\
\hline 2006 & 5.1 & -0.5 \\
\hline 2007 & 6.5 & 0.6 \\
\hline 2008 & 5.5 & -0.9 \\
\hline 2009 & -0.4 & -2.7 \\
\hline 2010 & 3.4 & -2.4 \\
\hline 2011 & 2.3 & -2.5 \\
\hline 2012 & -0.5 & -3 \\
\hline 2013 & 2.9 & -4.1 \\
\hline 2014 & 3.5 & 3.5 \\
\hline 2015 & 3.7 & -3 \\
\hline
\end{tabular}

Source: Ministry of Finance, Republic of Macedonia, Skopje. 


\section{REFERENCES}

Adama, C. - Bevan D. (2005), "Fiscal deficits and growth in developing countries", Journal of Public Economics, Vol. 89, pp. 570-598.

Acosta, S. - Morozumi A. (2013), "Can a government Enhance Long-Run Growth by Changing the Composition of Public Expenditure?" IMF Working Paper 13/162, Washington DC., International Monetary Fund, pp.8-10.

Agenor, P. (2010), "A Theory of Infrastructure- led Development", Journal of Economic Dynamics and Control, pp. 930-945.

Ahmad, H. - Millar M. (2000), "Crowding-out and Crow dinging Effects of the Components of Government Expenditure", Contemporary Economic Policy, pp. 123-135.

Aisen, A. - Hauner D. (2008), "Budget Deficit and Interest Rates", IMF Working Papers, 42, pp. 5-20.

Afonso, A. - Rault. C. (2007), "Should we Care for Structural Breaks When Assessing Fiscal Sustainability?” Technical University of Lisbon, pp. 22.

Arestis, P. - Sawyer M. (2006), "The Intertemporal Budget Constraint and the Sustainability of Budget Deficits", University of Leeds, pp.55.

Bergh, A. - Henkkerson M. (2011), "Government Size and Growth: A Survey and Interpretation of the Evidence”, Journal of Economic Surveys, pp. 870-880.

Cebula, R. (2003), "Budget Deficit and Real Interest Rates: Updated Empirical Evidence on Causality", Atlantic Economic Journal, 31, pp. 250-260.

Carneiro, F. - Joao F. (2005), "Government Revenues and Expenditures in GuineaBissau”, Journal of Economic Development, Texas, World Bank, pp. 17.

Durevall, D. - Henrekson M. (2011), "The Futile Quest for a Grand Explanation of Long-run Government Expenditure”, Journal of Public Economics, pp. 710-720.

Eisner, R. (1989), "Budget deficits: Rhetoric and Reality", Journal of Economics Perspectives, Vol. 3, pp.73- 78.

Fisher, S. (1993), “The role of macroeconomic factors in growth”, Journal of Monetary Economics, Vol. 32, pp. 484.

Gupta, S. - Baldacci E. (2005), "Fiscal policy, expenditure composition and growth in low- income countries", Journal of International Money and Finance, Vol, 24, pp. 440-460.

Gebhard, K. - Silika P. (2006), "Sustainability of Swiss Fiscal Policy", CESIFO Working Paper 1689, Switzerland, University of St. Gallen, pp. 30-50. 
Gemmell, N. - Au J. (2012), "Government Size, Fiscal Policy and the Level and Growth of Output: A Review of Recent Evidence", Working Paper in Public Finance 10/12, Victoria Business School, Wellington, pp. 20.

Huynh, D. (2007), "Budget Deficit and Economic Growth in Developing Countries: The case of Vietnam", Kansai Institute for Social and Economic Research, pp. 33.

Homes, J.M. - Otero J. (2007), "Are EU Budget Deficits Sustainable?" New Zealand, Waikato University, pp.18-35.

Keynes, J.M. (1936), "The General Theory of Employment, Interest and Money, Macmillan Cambridge University Press", Royal Economic Society, pp.10-20.

Kneller, R. - Gemmell, N. - Bleaney, M. (1999), "Fiscal policy and growth: evidence from OECD countries", Journal of Public Economics, pp. 170.

Kneller, R. - Misch, F. (2011), "What Does Ex- post Evidence Tell Us about the Output Effects of Future Tax Reforms?" Centre of European Economic Research, Mannheim, pp.10.

Kukk, K. (2008), "Fiscal policy effects on economic growth: Short- run vs long run", TTUWPE No. 167, Department of Economics Tallinn University of Technology, Estonia, pp.15-20.

Keho, Y. (2010), "Budget Deficits and Economic Growth: Causality Evidence and Policy Implications for WAEMU Countries", European Journal of Economics, Finance and Administrative Sciences, 18, pp. 100-105.

Lozano, I. (2008), "Budget Deficit, Money Growth and Inflation: Evidence from the Columbian case", Barradores de Economia, pp. 5-20.

Musgrave, R. A. (1989), "Public Finance in Theory and Practice", 5th international edition. pp.22.

Niepelt, D. (2007), "Starving the beast? Intra- generational conflict and balanced budget rules", European Economic Review, Vol.51, pp. 145.

Saleh, S.A. (2003), "The Budget Deficit and Economic Performance", University Wollongong Economics Working Paper Series, 12, pp. 20-40.

Sill, K. (2005), "Do Budget Deficits Cause Inflation?" Business Review, pp.20-30.

Vit, K. (2004), "The Possibilities of Budget Deficit Financing”, Ministry of Finance of the Czech Republic, pp. 1-15.

Zulal, S. (2007), "Endogenous Growth, Taxes and Government Spending: Theory and Evidence", Review of Development Economics, pp.120-130. 